\title{
Monocarboxylate Transporter 5
}

National Cancer Institute

\section{Source}

National Cancer Institute. Monocarboxylate Transporter 5. NCI Thesaurus. Code C107465.

Monocarboxylate transporter 5 (487 aa, $\sim 54 \mathrm{kDa}$ ) is encoded by the human SLC16A4 gene. This protein plays a role in the transport of monocarboxylates across the plasma membrane. 